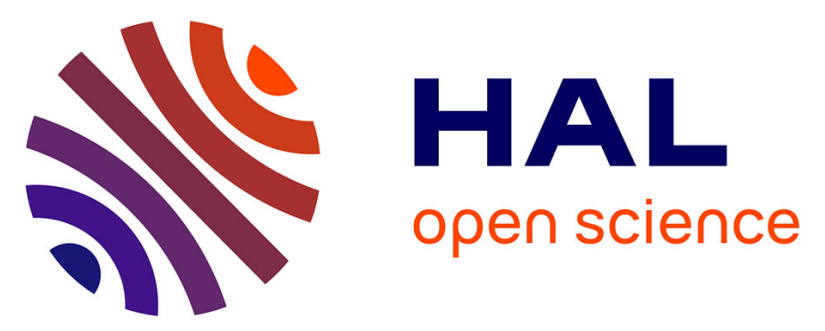

\title{
The Role of Technological Factors (Parameters of LPE) in Defect Generation and Formation of Properties of Magnetic Bubble Materials
}

\author{
V. Kostishyn, L. Letyuk, V. Medved', A. Morchenko, V. Myzina
}

\section{- To cite this version:}

V. Kostishyn, L. Letyuk, V. Medved', A. Morchenko, V. Myzina. The Role of Technological Factors (Parameters of LPE) in Defect Generation and Formation of Properties of Magnetic Bubble Materials. Journal de Physique IV Proceedings, 1997, 07 (C1), pp.C1-757-C1-758. 10.1051/jp4:19971310 . jpa00255078

\section{HAL Id: jpa-00255078 https://hal.science/jpa-00255078}

Submitted on 1 Jan 1997

HAL is a multi-disciplinary open access archive for the deposit and dissemination of scientific research documents, whether they are published or not. The documents may come from teaching and research institutions in France or abroad, or from public or private research centers.
L'archive ouverte pluridisciplinaire HAL, est destinée au dépôt et à la diffusion de documents scientifiques de niveau recherche, publiés ou non, émanant des établissements d'enseignement et de recherche français ou étrangers, des laboratoires publics ou privés. 


\title{
The Role of Technological Factors (Parameters of LPE) in Defect Generation and Formation of Properties of Magnetic Bubble Materials
}

\author{
V. Kostishyn, L. Letyuk, V. Medved', A. Morchenko and V. Myzina* \\ Moscow State Institute of Steel and Alloys (Technological University), Leninsky prospect, 4, Moscow, \\ 117936, Russia \\ * Institute of General Physics, Russian Academy of Science, Vavilov Street, 38, Moscow, 117942, Russia
}

\begin{abstract}
It is shown that in a value range of molar parameter $R_{5}=0.31-0.50$ the magnetic garnet films (YSmLuCa) $)_{3}(\mathrm{FeGe})_{5} \mathrm{O}_{12}$ have overstoichiometric amount of $\mathrm{Ca}^{2+}$ ions. Their concentration grows with the increase $\mathrm{R}_{5}$. It is established that charge neutralization of excess Ca2+ ions is executed predominantly by $\mathrm{V}_{\mathrm{O}^{2-}}^{+-} \mathrm{V}_{\mathrm{O}^{2-}}^{2+}$ vacancies. The contribution of oxygen vacancies in coercive force and magnetic anisotropy of films is determined.
\end{abstract}

\section{INTRODUCTION}

Magnetic garnet films with $(\mathrm{Ca}, \mathrm{Ge})$ - substitution have high values of Curie point and domain wall mobility. Due to these properties such film are a perspective material for manufacture of logic and storing devices on magnetic bubbles. The operational parameters, as well as presence of defects of above-stated materials are in many respects defined by the technological factors of growth. The purpose of given work was study of influence of molar parameter $\mathrm{R}_{5}$ on properties and defectivity of magnetic garnet films with (YSmLuCa) ${ }_{3}(\mathrm{FeGe})_{5} \mathrm{O}_{12}$ composition.

\section{OBJECTS OF RESEARCHES AND EXPERIMENTAL TECHNIQUES}

Films were fabricated by a method of liquid-phase epitaxy from a solution in flux $\mathrm{PbO}-\mathrm{B}_{2} \mathrm{O}_{3}$ on the substrates $\mathrm{Gd}_{3} \mathrm{Ga}_{5} \mathrm{O}_{12}$ with (111) crystallographic orientation. The molar parameters (molar ratios of components in the melt [1]) $R_{1}-R_{4}$ and $R_{6}$ were had similar values for all specimens. Parameter $R_{5}$ therewith varied and was equal: $0.31 ; 0.35 ; 0.48$ and 0.50 . The film growth rate ranges from 0.75 to $0.80 \mu \mathrm{m} / \mathrm{min}$.

The coercive force $\mathrm{H}_{c}$ and field of effective magnetic anisotropy $\mathrm{H}_{\mathrm{k}}$ were determined by standard techniques [1]. The difference between experimentally measured $\left(\mathrm{H}_{\mathrm{k}}\right)$ and designed $\left(\mathrm{H}_{\mathrm{k}}\right)$ values was defined as:

$\Delta \mathrm{H}_{\mathrm{k}}=\mathrm{H}_{\mathrm{k}}-\mathrm{H}_{\mathrm{k}}^{\prime}$,

where $\mathrm{H}_{\mathrm{k}}^{\prime} \quad=\mathrm{H}_{\mathrm{G}}+\mathrm{H}_{\sigma}-\mathrm{M}_{\mathrm{S}}, \mathrm{H}_{\mathrm{G}}$ и $\mathrm{H}_{\sigma}$ are the growth- and stress-induced (caused by discrepancy of lattice parameters between film and substrate) components of uniaxial anisotropy, Ms is saturation magnetization.

For study of film defectivity the following methods were used: X-ray microscopic microanalysis, X-ray photoelectron spectroscopy (XRPES), X-ray diffraction, X-ray topography, thermostimulated conduction current in short circuit regime (TSCCSC) and polarization-optic technique. Microanalysis of samples has allowed to find out that the $\mathrm{R}_{5}$ value insignificantly influences the concentration of rare earth ions, $\mathrm{Fe}^{3+}$ ions and impurity ions of $\mathrm{Pb}^{2+}$ and $\mathrm{Pt}^{4+}$, appearing during growth. At the same time, in all films without exception the presence of overstoichiometric $\mathrm{Ca}^{2+}$ ions was found out. As $\mathrm{R}_{5}$ increases from 0.31 to 0.50 , the overstoichiometric $\mathrm{Ca}^{2+}$ concentration increases from 0.03 to 0.11 in formula unit.

\section{RESULTS}

Measurements of magnetic parameters of samples have found out that the increase of parameter $\mathrm{R}_{5}$ (representing of overstoichiometric $\mathrm{Ca}^{2+}$ concentration) brings to growth of values $H_{c}$ and $\Delta H_{k}$. The dependencies $H_{c}\left(R_{5}\right)$ and $\Delta H_{k}\left(R_{5}\right)$ are shown in fig.1. The increased values of $H_{c}$ and $H_{k}$ (in comparison with Ga-substituted compositions) are characteristic feature of magnetic garnet films of a $(\mathrm{Ca}, \mathrm{Ge})$-system [1] and in doing so the nature of high values of this parameters is at present finally not established. The linear dependence between coercive force and molar parameter $\mathrm{Rs}$ $\left(\mathrm{R}_{5}=0.03 \div 0.625\right)$ was received also by Hibiya $T$. with the co-authors [3] for (YSmLuCa $)_{3}\left(\mathrm{FeGe}_{5} \mathrm{O}_{12}\right.$ and $(\mathrm{YEuTmCa})_{3}(\mathrm{FeGe})_{5} \mathrm{O}_{12}$ films. 


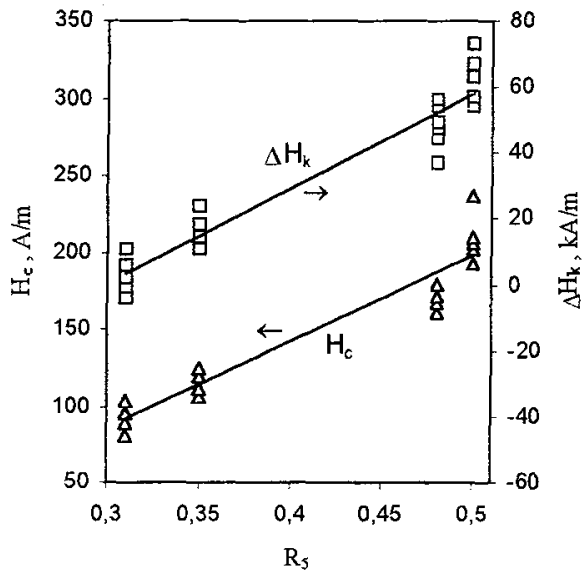

Figure 1: The Rs-dependence of the magnetic film characteristics.
The film etching in $\mathrm{H}_{3} \mathrm{PO}_{4}$, polarization-optic measurements, X-ray topography and X-ray crystallographic analysis, TSCCSC, as well as data, given by Shupegin M.L. [4], allows to conclude that the increased values of $H_{c}$ are not stipulated by action of non-uniform elastic stress or fixing (pinning) of domain boundaries on dislocations. It is standard opinion that the redundant $\mathrm{Ca}^{2+}$ ions should be compensated by the $\mathrm{Fe}^{4+}$ ions (see, for example, [1]), because on a microanalysis data the tetravalent ions, such as $\mathrm{Ge}^{4+}, \mathrm{Pt}^{4+}$ are not enough for this.

For all available specimens the TSCCSC spectra consist of two peaks with temperature maxima at $\mathrm{T}_{\mathrm{m}_{1}}=(443 \div 445) \mathrm{K}$ and $\mathrm{T}_{\mathrm{m}_{2}}=503 \mathrm{~K}$. To greater concentration of redundant $\mathrm{Ca}^{2+}$ ions there corresponds larger intensity of peaks. It was established that these peaks correspond to deep capture centres with activation energy $\mathrm{E}_{\mathrm{t}_{1}}=0.87 \mathrm{eV}$ and $E_{t_{2}}=1.1 \mathrm{eV}$ respectively. Results by Larsen P.K. and Metselaar R. [5,6] and our calculations given the basis to conclude that the found out local centres are stipulated by presence of oxygen vacancies in objects of research.

In this case the low-temperature peak corresponds to $\mathrm{V}_{\mathrm{O}^{2-}}^{+}$vacancy $\left(\mathrm{F}^{+}\right.$-centre) and high-temperature one to $\mathrm{V}_{\mathrm{O}^{2-}}^{2+}$ vacancy. In $[3,7]$ it is supposed that the reason of high coercivity of magnetic garnet films of (Ca,Ge)-systems are oxygen vacancy. According to estimates on the basis of our data the concentrations of these vacancies constitute:

$\mathrm{N}_{\mathrm{t}_{1}}=(5.0 \div 7.2) \cdot 10^{18} \mathrm{~V}_{\mathrm{O}^{2-}}^{+2} \mathrm{sm}^{-3} ; \mathrm{N}_{\mathrm{t}_{2}}=(5.5 \div 7.8) \cdot 10^{18} \mathrm{~V}_{\mathrm{O}^{2-}}^{2+} \mathrm{sm}^{-3}$ for composition with content of 0.03 redundant

$\mathrm{Ca}^{2+}$ ions per formula unit (that corresponds to concentration $1.27 \cdot 10^{20} \mathrm{sm}^{-3}$ );

$\mathrm{N}_{\mathrm{t}_{1}}=(1.5 \div 2.2) \cdot 10^{19} \mathrm{~V}_{\mathrm{O}^{2-}}^{+} \mathrm{sm}^{-3} ; \mathrm{N}_{\mathrm{t}_{2}}=(1,3 \div 2,5) \cdot 10^{19} \mathrm{~V}_{\mathrm{O}^{2-}}^{2+} \mathrm{sm}^{-3}$ for composition with content of 0.1 redundant

$\mathrm{Ca}^{2+}$ ions per formula unit (that corresponds to concentration $4.22 \cdot 10^{20} \mathrm{sm}^{-3}$ ).

However, the concentration of $\mathrm{V}_{\mathrm{O}^{2-}}^{+}$and $\mathrm{V}_{\mathrm{O}^{2-}}^{2+}$ vacancies has not enough for complete charge neutralization of

$\mathrm{Ca}^{2+}$ ions. As far as XRPES have not found out the $\mathrm{Fe}^{4+}$ ions and the p-centres $\mathrm{O}^{-}$, in all probability, the part of redundant $\mathrm{Ca}^{2+}$ ions passes in interstitial sites. It can promote precipitation of neutral oxygen vacancies (F-centres) into clusters causing to the increased $\mathrm{H}_{c}$ values. As one of variants of such clusterization, it is probably the formation of "vacancy pores" from F-centres about small groups of interstitial calcium ions [7]. A reasoning conducted for coercive force holds true and for anisotropy. When the oxygen vacancies have enough large concentration (up to $1.10^{-3 / f}$.u.) and complete ordering, they can result to occurrence of uniaxial anisotropy with $\mathrm{K}_{\mathrm{G}}=5 \mathrm{~kJ} / \mathrm{m}^{3}$, that is $2 \div 5$ times more than the value under observation [8]. Thus, the model of ordered distribution of oxygen vacancies is quite applicable for the explanation of $\Delta \mathrm{H}_{\mathrm{k}}$ growth with the increase $\mathrm{R}$.

\section{CONCLUSION}

As a result of our researches it is established: a magnetic garnet films (YSmLuCa) $)_{3}(\mathrm{FeGe})_{5} \mathrm{O}_{12}$ at $\mathrm{R}_{5}=0,31 \div 0,50$ have the overstoichiometric content of $\mathrm{Ca}^{2+}$ ions. Their charge neutralization is executed predominantly by $\mathrm{V}_{\mathrm{O}^{2-}}^{+}$and $\mathrm{V}_{\mathrm{O}^{2-}}^{2+}$ vacancies. Specified vacancies result in the increased values $\mathrm{H}_{c}$ and $\mathrm{H}_{k}$ of $(\mathrm{Ca}, \mathrm{Ge})$-substituted films at $\mathrm{Ca}^{2+} / \mathrm{Ge}^{4+}>1$. In this case the growth magnetic anisotropy is stipulated by two factors: occupation of non-equivalent dodecahedral positions by rare-earth ions; oxygen vacancy ordering determined, obviously, by distribution of $\mathrm{Ca}^{2+}$ ions.

\section{References}

[1] Elements and devices on magnetic bubbles: Handbook (Radio i svyaz, Moscow, 1987) (in Russian).

[2] Gorokhovatsky Yu.A. and Bordovsky G.A. Thermoactivation current spectroscopy of high-resistance semiconductors and dielectrics (Science, Moscow, 1991) (in Russian).

[3] Hibiya T., Hidaka Y. and Suzuki K., J.Appl.Phys. 49 (1978) 2765-2768.

[4] Shupegin M.L. Development of principles of regulation of induced coercivity in orthoferrites and magnetic garnets. Dissertation (MISA, Moscow, 1980) (in Russian).

[5] Larsen P.K. and Metselaar R., J. Solid State Chem. 12 (1975) 253-258.

[6] Larsen P.K. and Metselaar R., Phys.Rev.B. 8 (1977) 2016-2022.

[7] Tkalich A.K. Influence of point defects and concentration inhomogeneities on properties of single-crystal magnetic garnet films. Dissertation. (MISA, Moscow, 1992) (in Russian)

[8] Stacy W.T. and Rooymans C.J., Solid State Communs 9 (1971) 2005-2008. 